01,11

\title{
In situ TEM-исследование фазовых превращений в нестехиометрическом сплаве Гейслера $\mathrm{Ni}_{46} \mathrm{Mn}_{41} \ln _{13}$
}

\author{
() Д.Д. Кузнецов ${ }^{1}$, Е.И. Кузнецова ${ }^{2}$, А.В. Маширов ${ }^{1}$, А.С. Лошаченко ${ }^{3}$, Д.В. Данилов ${ }^{3}$, \\ Г.А. Шандрюк ${ }^{4}$, В.Г. Шавров ${ }^{1}$, В.В. Коледов ${ }^{1}$ \\ ${ }^{1}$ Институт радиотехники и электроники им. В.А. Котельникова РАН, \\ Москва, Россия \\ ${ }^{2}$ Институт физики металлов им. М.Н. Михеева УрО РАН, \\ Екатеринбург, Россия \\ ${ }^{3}$ МРЦ по направлению „Нанотехнологии“, Научный парк, Санкт-Петербургский государственный университет, \\ Санкт-Петербург, Россия \\ ${ }^{4}$ Институт нефтехимического синтеза им. А.В. Топчиева РАН, \\ Москва, Россия \\ E-mail: kuznetsov.dmitry89@gmail.com
}

Поступила в Редакцию 8 июля 2021 г.

В окончательной редакции 13 июля 2021 г.

Принята к публикации 16 июля 2021 г.

\begin{abstract}
Представлены исследования метамагнитоструктурного превращения мартенситного типа в сплаве $\mathrm{Ni}_{46} \mathrm{Mn}_{41} \mathrm{In}_{13}$ с магнитной памятью формы и обратным магнитокалорическим эффектом. Характерные температуры начала прямого превращения $M_{s}=253 \mathrm{~K}$ и его конца $M_{f}=164 \mathrm{~K}$, а также обратного $A_{s}=203 \mathrm{~K}$ и $A_{f}=236 \mathrm{~K}$ соответственно, определялись методом дифференциальной сканирующей калориметрии. Характерные особенности превращения: понижение температуры начала прямого мартенситного и наличие остаточной фазы аустенита, и предмартенситные состояния изучались с помощью просвечивающей электронной микроскопии. Проведена оценка толщины материала, при которой блокируется мартенситное превращение, которая составила $50 \mathrm{~nm}$.
\end{abstract}

Ключевые слова: мартенситное превращение, метамагнитоструктурное превращение, предмартенситные состояния

DOI: 10.21883/FTT.2021.11.51568.10s

\section{1. Введение}

В последние годы сплавы Гейслера систем Ni-Mn-Z $(\mathrm{Z}=\mathrm{Ga}, \mathrm{In}, \mathrm{Sn})$ привлекают большой интерес исследователей, как ферромагнитные сплавы с эффектом памяти формы (ЭПФ) вследствие уникальных физических свойств и их потенциального применения для создания магнитных актюаторов, спинтронных устройств и твердотельных магнитных охлаждающих систем [1-7].

Сплавы на основе системы Ni-Mn-In являются классом материалов, проявляющих эффект магнитной памяти формы, сопровождающий мартенситное превращение из кубической фазы (аустенит) в низкосимметричную фазу (мартенсит). Несмотря на интенсивные исследования, механизм мартенситного превращения в этой системе остается до конца не ясным. В сплавах, способных испытывать мартенситное превращение наблюдаются, так называемые, предпереходные явления, в которых метастабильная предмартенситная фаза рассматривается как предшественник термодинамически стабильной мартенситной фазы. При этом материал демонстрирует аномалию упругих, тепловых, электрических и магнитных свойств. Эти аномалии напрямую связаны с эволюцией предмартенситной структуры, которая может рассматриваться как зарождающаяся мартенситная фаза или, как фактически независимая фаза перед мартенситным превращением, о чем свидетельствуют исследования сплавов на основе Ti-Ni [8].

Предмартенситная фаза в системе Ni-Mn-In сохраняет общую кубическую симметрию исходной высокотемпературной аустенитной фазы L2 $2_{1}$, но, как показывают электронно-микроскопические исследования, представляет собой сложное состояние в нанометровом масштабе, с образованием тонкой, регулярной структуры, называемой твидом. Твидовый контраст наблюдался во многих сплавах, проявляющих превращение по мартенситному типу, соединении на основе $\mathrm{Y}-\mathrm{Ba}-\mathrm{Cu}-\mathrm{O}$ и других сплавах Гейслера [9-11]. Многие существующие в настоящее время объяснения аномалий предмартенситных явлений, в том числе, твидовой структуры, основаны на эффектах, связанных с флуктуациями состава и химическим расслоением, которые вызывают состояние деформации решетки [12]. Хачатурян с соавторами предполагают, что предмартенситная твидовая структура является результатом когерентных нанодисперсных выделений, встраиваемых в исходную фазу на начальной стадии распада и, с учетом этого, предлагают концепцию „псевдоспинодального распада“ $[13]$. В последнее время эти представления пересматриваются с учетом 
новых теоретических подходов и экспериментальных результатов [14].

Кроме того, в последнее время многочисленные исследования сконцентрировались на изучении так называемых „размерных эффектов“, которые играют существенную роль в подавлении процесса мартенситного превращения [15]. Авторами работы [16] установлено, что в наноструктурированом $\mathrm{Ni}$-Ті термоиндуцированное мартенситное превращение полностью подавляется при размере зерна менее $50 \mathrm{~nm}$. Аналогичное исследование в тонких пленках $\mathrm{Ni}$-Ti показало, что мартенситное превращение подавляется, когда толщина пленки уменьшается до $50 \mathrm{~nm}[17]$.

В данной работе изучались особенности метамагнитного мартенситного превращение сплава $\mathrm{Ni}_{46} \mathrm{Mn}_{41} \mathrm{In}_{13}$ в тонкой клиновидной фольге. Исследовались предмартенситные эффекты, влияние магнитного поля и толщины фольги на температуру мартенситного превращения.

\section{2. Образцы и методика эксперимента}

Поликристаллические образцы сплава $\mathrm{Ni}_{46} \mathrm{Mn}_{41} \mathrm{In}_{13}$ в виде слитков весом около $30 \mathrm{~g}$ были изготовлены из высокочистых исходных металлов $\mathrm{Ni}, \mathrm{Mn}, \mathrm{In}$ (99.99\%) методом дуговой плавки в атмосфере аргона на холодном поду с тремя переворотами и переплавками. С целью гомогенизации проводился отжиг слитков в вакууме при температуре $900^{\circ} \mathrm{C}$ в течение суток с последующим медленным охлаждением в печи до комнатной температуры.

Характерные температуры начала и конца прямого и обратного метамагнитоструктурного превращения, температуру Кюри определяли методом дифференциальной сканирующей калориметрии (ДСК) на установке METTLER TOLEDO DSC ${ }^{+}{ }^{+}$в температурном интервале от -173 до $327^{\circ} \mathrm{C}$.

Полевые зависимости намагниченности образца от температуры проводились на вибрационном магнитометpe VersaLab „Quantum Design“ в полях 1 T, 2T, 3 T по следующему протоколу: zero field cooling (ZFC); field cooling (FC); field heating (FH) в интервале температур от 50 до $400 \mathrm{~K}$.

Кристаллическая структура образца исследовалась в температурном диапазоне $100-340 \mathrm{~K}$ при помощи просвечивающего электронного микроскопа (ПЭМ) Carl Zeiss Libra 200FE (ускоряющее напряжение $200 \mathrm{kV}$ ) с энергетическим ОМЕГА фильтром, энергодисперсионным детектором рентгеновских излучений Oxford Instruments X-Max 80 и с двухосевым криоаналитическим держателем Gatan Model 636 с контроллером температуры Model 900 SmartSet cold stage controller.

Электронно-микроскопические исследования проводились на фольгах, полученных стандартными методами в режимах светло- и темнопольного получения изображений. Для идентификации локальных фаз использовался метод микродифракции. Для прямого определения толщины фольги, после проведения микроскопических исследований, в изучаемом месте был произведен срез с помощью сфокусированного ионного пучка $\mathrm{Ga}$ на двулучевой рабочей станции Carl Zeiss Auriga Laser.

Электронно-микроскопические исследования и подготовка фольг для ПЭМ были выполнены в Междисциплинарном ресурсном центре по направлению „Нанотехнологии“, ЦКП Научный парк СПбГУ, г. Санкт-Петербург.

\section{3. Обсуждение результатов}

Методом ДСК были определены температуры начала и конца прямого $\left(M_{s}\right.$ и $\left.M_{f}\right)$ и обратного $\left(A_{s}\right.$ и $\left.A_{f}\right)$ метамагнитоструктурных переходов и температура Кюри $\left(T_{c}\right): M_{s}=253 \mathrm{~K}, M_{f}=164 \mathrm{~K}, A_{s}=203 \mathrm{~K}$, $A_{f}=236 \mathrm{~K}, T_{c}=323 \mathrm{~K}$ (при охлаждении из аустенитной фазы) и $329 \mathrm{~K}$ (при нагреве из мартенситной фазы). Термограмма представлена на рис. 1 .

Данные полевых зависимостей намагниченности показывают, что чувствительность материала к магнитному полю составила $K_{M s}=7 \mathrm{~K} / \mathrm{T}$ (рис. 2), т.е. прикладываемые внешние магнитные поля смещают температуру метамагнитоструктрного превращения на $7 \mathrm{~K}$ в сторону низких температур.

Выявлена зависимость температуры начала метамагнитоструктурного превращения мартенситного типа от толщины образца в виде клинообразной фольги. Обнаружено, что мартенситная фаза при прямом мартенситном превращении, в тонких областях фольги с толщиной менее $150 \mathrm{~nm}$, начинает появляться при $M_{s}=215 \mathrm{~K}$ (т.е. при температурах ниже, чем в объ-

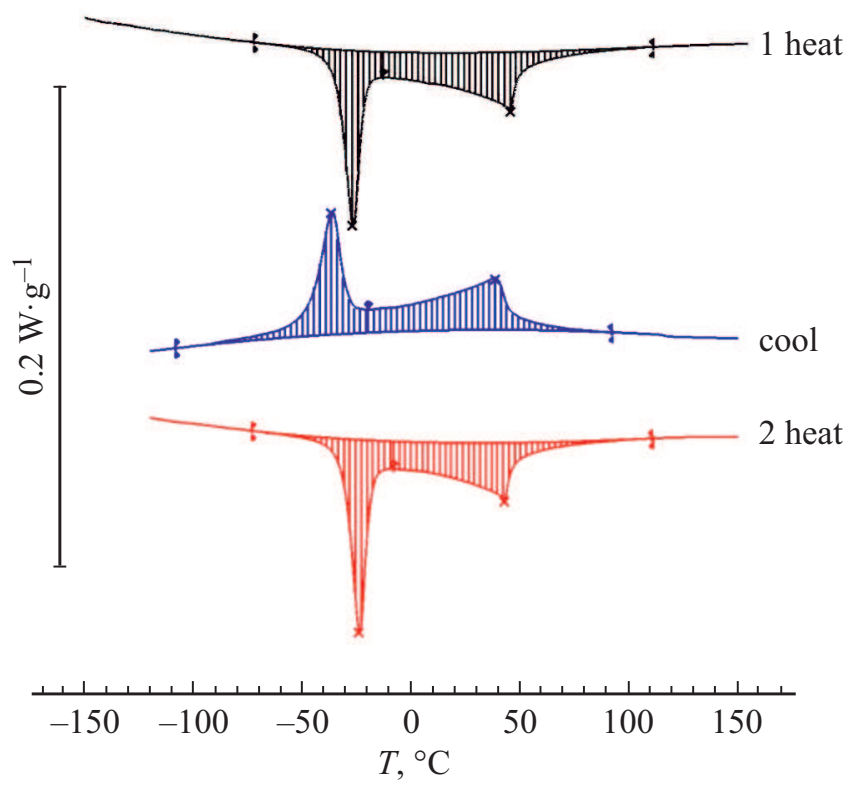

Рис. 1. Термограмма для сплава $\mathrm{Ni}_{46} \mathrm{Mn}_{41} \mathrm{In}_{13}$ : 1 heat измерение при первом нагреве от -173 до $327^{\circ} \mathrm{C}$; cool измерение при охлаждении от 327 до $-173^{\circ} \mathrm{C}$; 2 heat измерение при втором нагреве от -173 до $327^{\circ} \mathrm{C}$. 


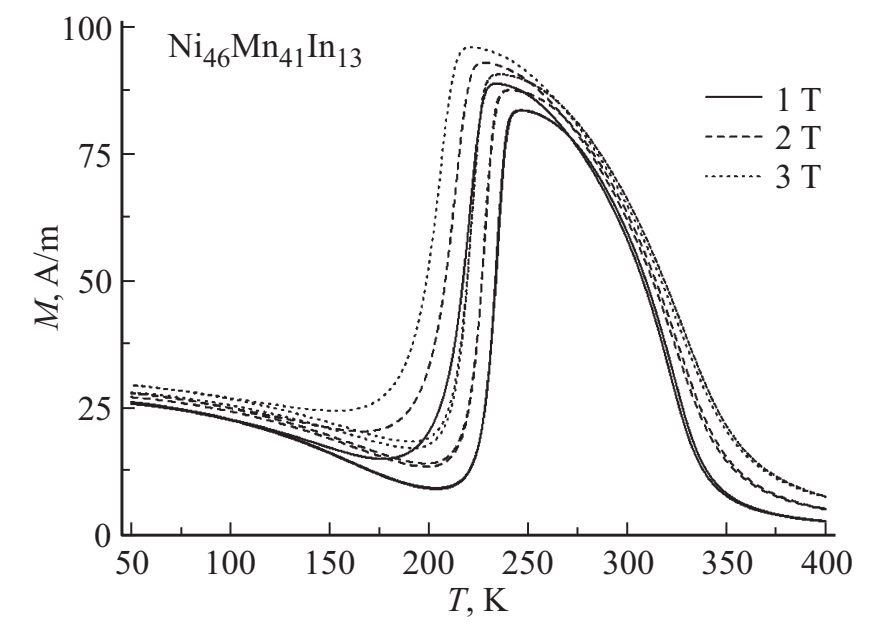

Рис. 2. График зависимости намагниченности $(M(\mathrm{~A} / \mathrm{m}))$ образца от температуры $(T(\mathrm{~K}))$. емном материале) после первого цикла охлаждениенагрев-охлаждение, после второго цикла $M_{s}=210 \mathrm{~K}$ и после третьего $M_{s}=208 \mathrm{~K}$, вероятно, это связано с накоплением дефектов и/или окислением материала, это явление требует отдельного исследования. Дальнейшее снижение температуры для каждого из циклов, приводит к увеличению доли мартенсита, однако, превращение блокируется на расстоянии примерно $600 \mathrm{~nm}$ от края образца при толщине пластины менее $50 \mathrm{~nm}$, таким образом образование мартенситной структуры здесь не наблюдается даже при температуре жидкого азота (рис. 3).

Так как наблюдаемые явления имеют определенные перспективы из-за потенциального применения исследуемого сплава в наномасштабных устройствах, исследование особенностей мартенситного превращения в тонкой клиновидной фольге представляется крайне интересным.
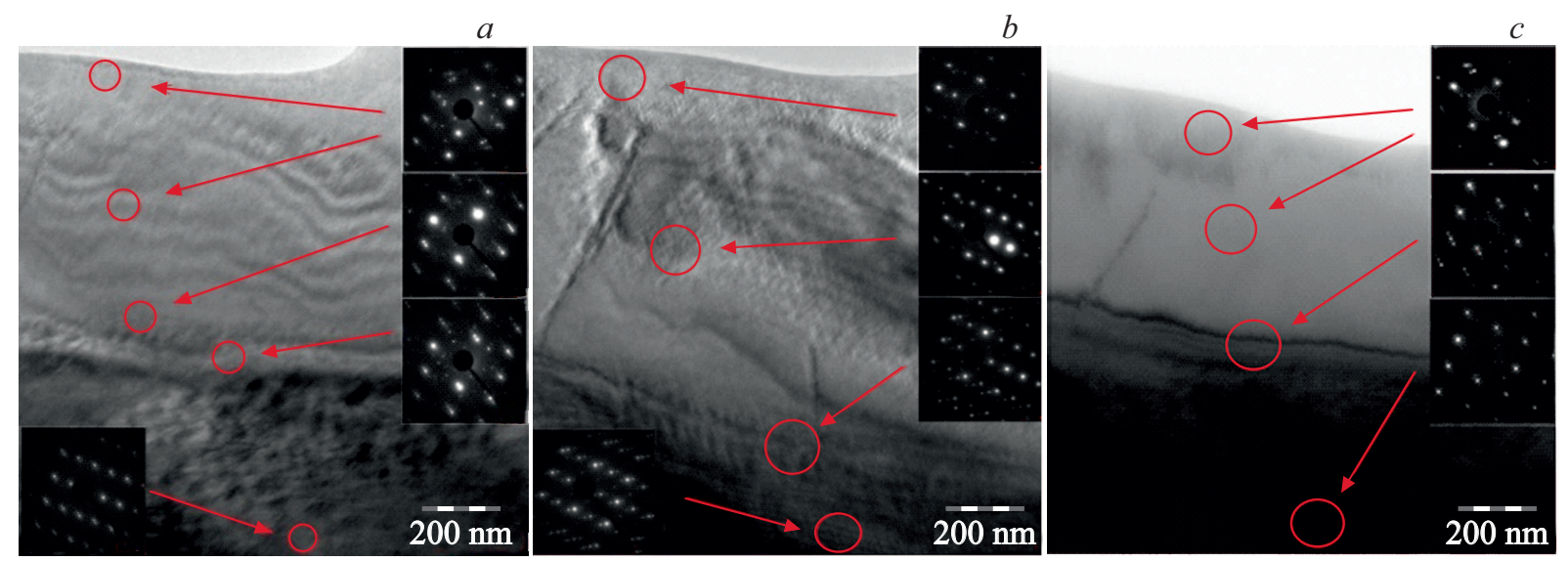

Рис. 3. Светлопольные изображения и дифракционные картины выделенных участков сплава $\mathrm{Ni}_{46} \mathrm{Mn}_{41} \mathrm{In}_{13}$ при температуре $215 \mathrm{~K}(a), 208 \mathrm{~K}(b), 100 \mathrm{~K}(c)$.

$a$

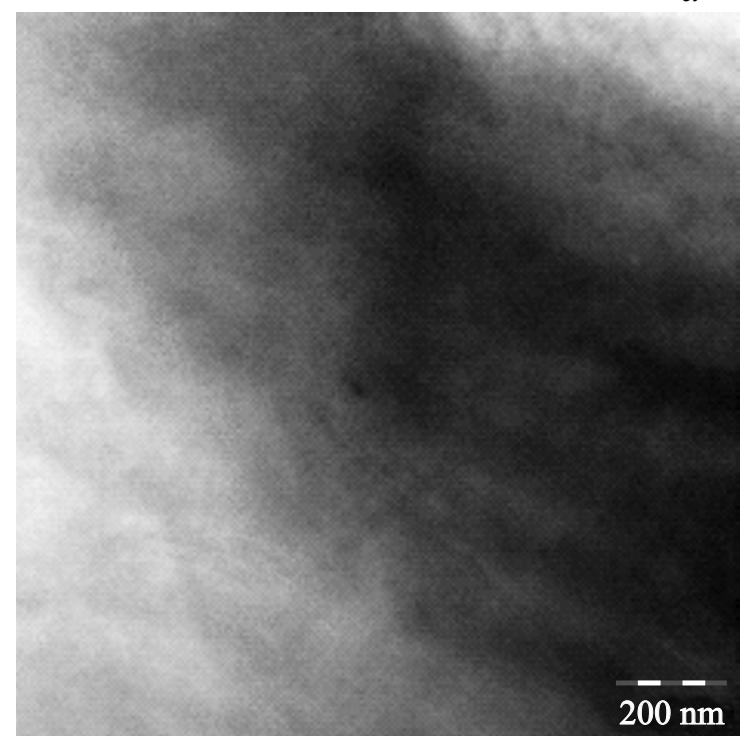

$b$

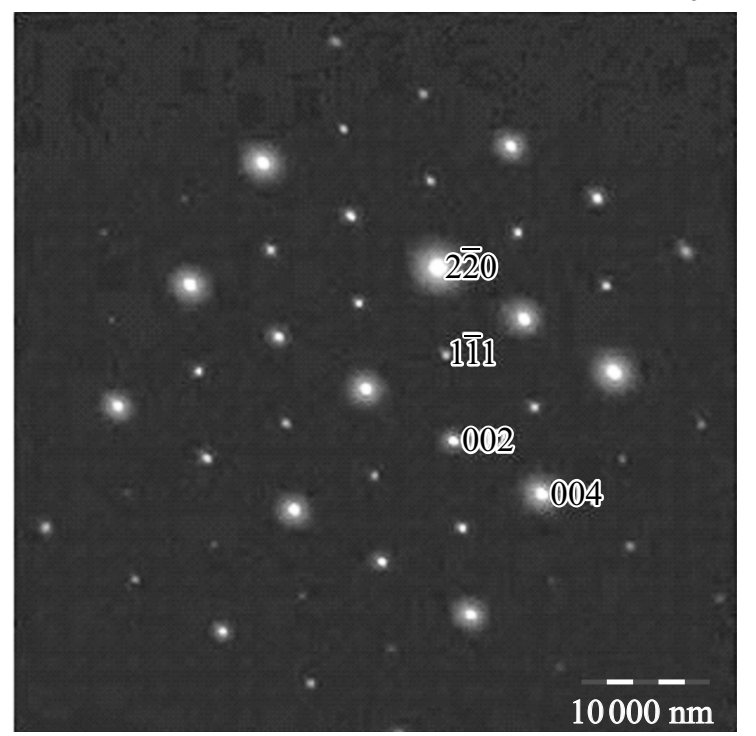

Рис. 4. Микроструктура аустенитной фазы сплава $\mathrm{Ni}_{46} \mathrm{Mn}_{41} \mathrm{In}_{13}: a-$ светлопольное изображение; $b-$ электронограмма, ось зоны $[110]_{\mathrm{L} 21}$. 
$a$

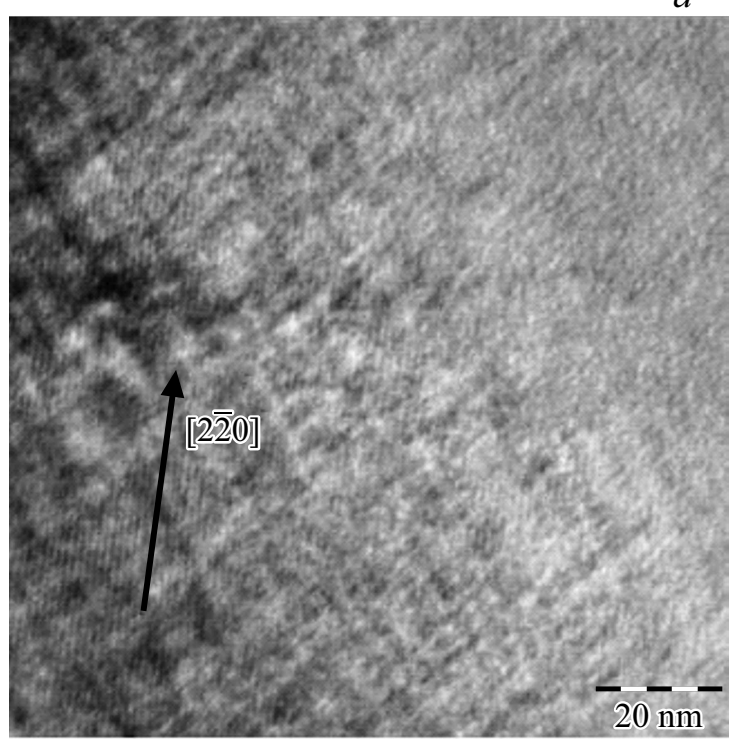

$c$

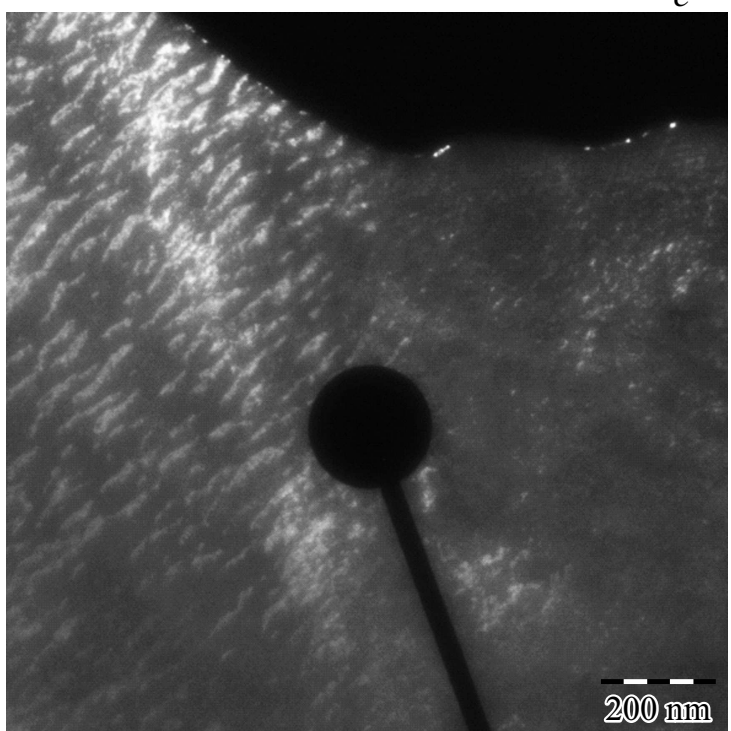

$b$

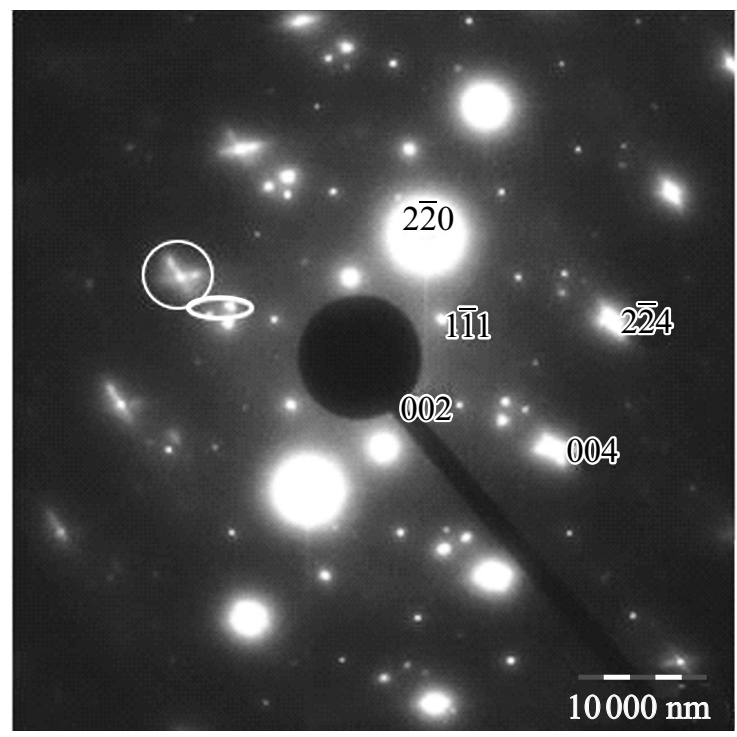

$d$

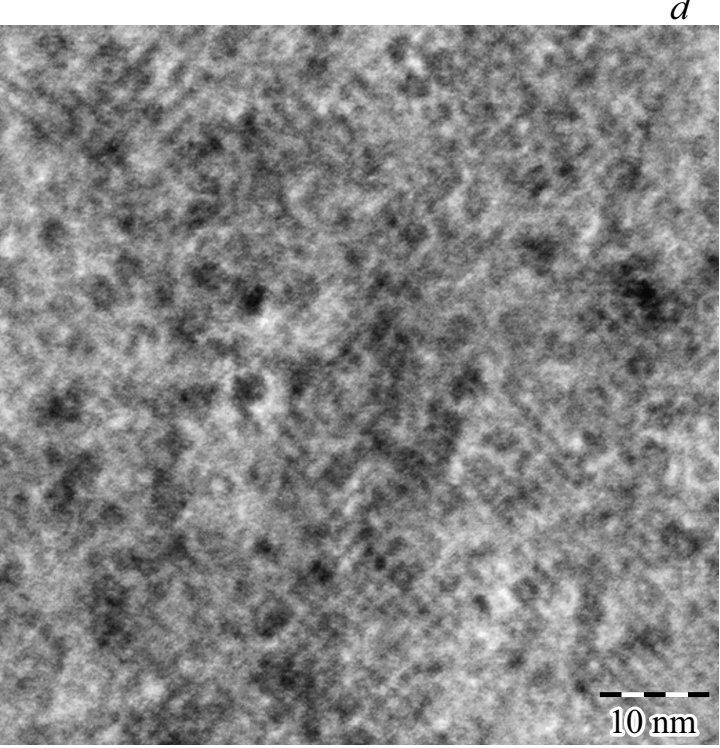

Рис. 5. Микроструктура сплава $\mathrm{Ni}_{46} \mathrm{Mn}_{41} \mathrm{In}_{13}: a-$ светлопольное изображение; $b-$ электронограмма, ось зоны $[110]_{\mathrm{L} 21} ; c-$ темнопольное изображение в рефлексе, обведенном эллипсом на электронограмме; $d$ - светлопольное изображение при большем увеличении.

Влияние „размерных эффектов“ на основные параметры, характеризующие мартенситное превращение, такие как $M_{s}$, рассматривают, в основном, с позиции наличия энергетических барьеров, связанных с энергией границ раздела аустенит-мартенсит и мартенсит-мартенсит, которые замедляют или даже полностью блокируют превращение [16]. Кроме того, закономерности перестройки при мартенситном превращении вытекают из ориентационных соотношений между атомно-кристаллическими решетками аустенитной и мартенситной фаз и их микроструктурных особенностей. Учитывая, что структура нестехиометрических сплавов на основе соединения $\mathrm{Ni}-\mathrm{Mn}$-In менее изучена, чем структура стехиометри- ческого соединения, подробно рассмотрим эволюцию тонкой структуры сплава $\mathrm{Ni}_{46} \mathrm{Mn}_{41} \mathrm{In}_{13}$.

Аустенит. На рис. 4 представлена структура аустенитной (рис. 4, $a$ - светлопольное изображение) фазы исследованного сплава $\mathrm{Ni}_{46} \mathrm{Mn}_{41} \mathrm{In}_{13}$.

Микродифракционная картина (рис. $4, b$ ) соответствует одному из возможных вариантов оси зоны [110] аустенита с решеткой L2 $2_{1}(a=6.17 \AA)$. Наличие $(111)$ сверхструктурных рефлексов указывает на хорошо упорядоченную фазу L2 1 в этой системе. Наблюдающийся твидовый контраст (рис. 5,a), сопровождается определенным типом диффузного рассеяния (обведено кружком на рис. $5, b)$. Расстояние между полосками твидовой структуры составляет 5-10 nm. В левой части рис. 5, $a$ 


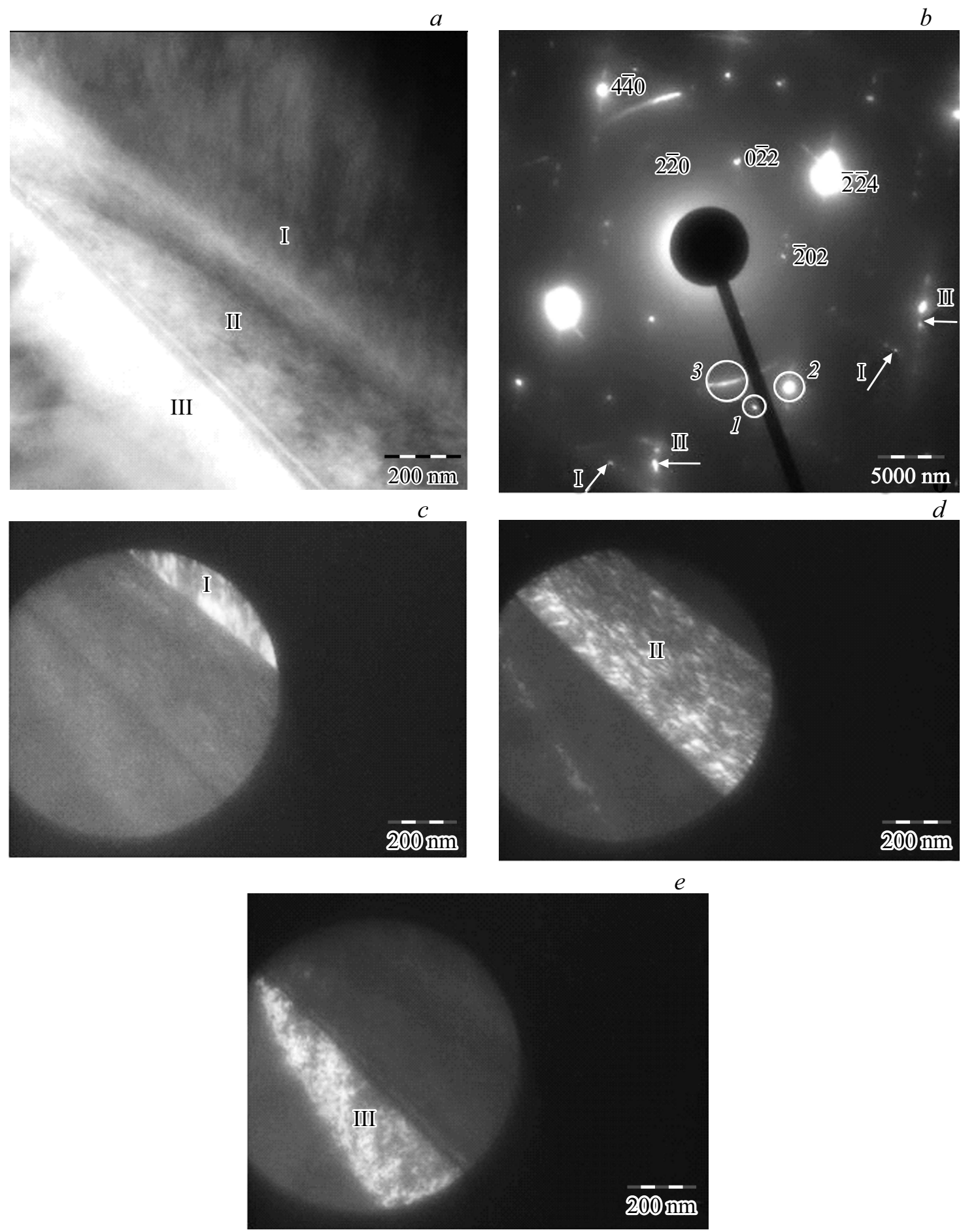

Рис. 6. Микроструктура сплава $\mathrm{Ni}_{46} \mathrm{Mn}_{41} \mathrm{In}_{13}: a-$ светлопольное изображение; $b$ - электронограмма, ось зоны $[111]_{\mathrm{L} 21}$; $c$ - темнопольное изображение в рефлексе $1 ; d-$ темнопольное изображение в рефлексе $2 ; e-$ темнопольное изображение в азимутально размытом рефлексе 3 .

наблюдается дополнительный контраст — тонкие протяженные полосы, параллельные плоскости (220). Расстояние между полосками примерно $1.2 \mathrm{~nm}$, что соответствует шести расстояниям между плоскостями (220). На темнопольном изображении (рис. 5,c), полученном в двух из тройки рефлексов (обведено эллипсом на рис. $5, b$ ), наблюдается модулированная структура другого типа. Эта структура похожа на классическую модулированную структуру концентрационного типа, созданную полями напряжений, свидетельствующими о локальных искажениях решетки. Так как модулированная мартенситная структура создается путем периодического смещения 
плоскости (110) в направлении $\langle 110\rangle$ аустенитной фазы или плоскости $(112)$ в направлении $\langle 111\rangle$ аустенитной фазы, предпереходные явления представляют собой смещения атомов в сторону будущей фазы. Смещения атомов из положений равновесия вызывают деформации решетки, которые проявляются в возникновении модулированных структур, в частности твидовой микроструктуры. Такие твидовые домены, возникающие в предмартенситном состоянии, вероятно, служат местами зарождения мартенсита. При этом на дифракционных картинах появляются сателлиты и характерное диффузное рассеяние.

В нестехиометрическом сплаве могут происходить процессы концентрационного расслоения, сопровождающиеся выделением нанодисперсных частиц, когерентных или частично когерентных матрице. Это, в свою очередь, приведет к возникновению внутренних напряжений и появлению черно-белого и твидового контраста. На рис. $5, d$, полученном при большем увеличении, наблюдаются наноразмерные (около $2-3 \mathrm{~nm}$ ) равномерно распределенные выделения, хорошо различимые на фоне твидового контраста. Подобный контраст, в виде доменной структуры, наблюдался в результате низкотемпературного спинодального распада нестехиометрического соединения $\mathrm{YBa}_{2} \mathrm{Cu}_{3} \mathrm{O}_{7-\delta}$ и был обусловлен выделением частиц обогащенной кислородом ортофазы в обедненной кислородом матрице [18].

Сосуществование аустенита и мартенсита. На рис. 6 и 7 представлены микрофотографии и дифракционные картины от областей аустенита и областей, испытавших мартенситное превращение. На рис. 6, $a$ представлена структура, состоящая из двух пластинчатых кристаллов мартенсита. По наблюдающимся ориентациям полосчатого контраста внутри мартенситных кристаллов и соответствующих ему направлений рядов рефлексов на электронограммах (указаны стрелками на рис. $6, b$ ), можно судить о присутствии двух различных ориентировок мартенсита, обозначенных I и II. Сравнение темнопольных и светлопольных изображений и сопоставление их с соответствующими электронограммами показывает, что одна система рефлексов принадлежит мартенситу с ориентировкой I (рис. 6,c), а вторая - с ориентировкой II (рис. 6, $d$ ). На рис. 7 представлены электронограммы, полученные от выделенных апертурой участков, принадлежащих каждой ориентировке. Внутри пластины I наблюдается полосчатый контраст, перпендикулярный рядам расщепления рефлексов на электронограмме.

На темнопольном изображении (рис. $6, e$ ), снятом в азимутально размытом рефлексе, принадлежащем $\mathrm{L} 2_{1}$ решетке аустенита (на электронограмме рис. $6, b$ обозначен 3), наблюдается третья ориентация кристалла клиновидный участок, обозначенный III. Этот остаточный аустенит находится между пластинами мартенсита в виде клинообразной вставки, имеющей фрагментированную нанодоменную структуру, атомноупорядоченную по типу L2 $2_{1}$. Микроструктура зажатого между

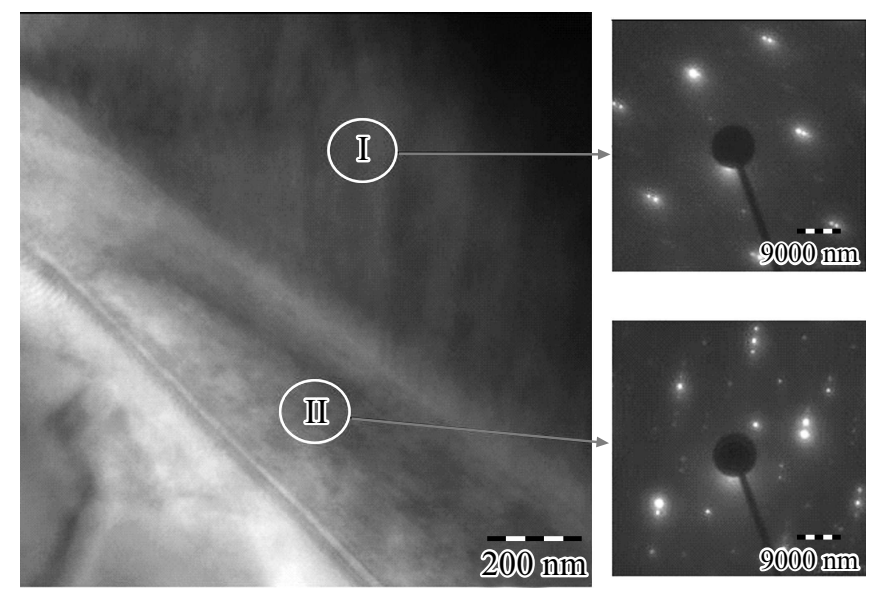

Рис. 7. Светлопольное изображение сплава $\mathrm{Ni}_{46} \mathrm{Mn}_{41} \mathrm{In}_{13}$ и электронограммы, полученные от двух различных ориентировок мартенсита.

двумя мартенситными фазами остаточного аустенита характеризуется высокими внутренними напряжениями, о чем свидетельствует азимутальное размытие рефлексов. Кроме того, азимутальное размытие рефлексов может отражать и клинообразную форму аустенитной фазы и разориентировку составляющих аустенит нанодоменов относительно друг друга. То, что фрагментации подвергается только аустенитная фаза, говорит монокристальный тип электронограмм, на которых наблюдаются лишь определенные, принадлежащие исключительно аустенитной фазе рефлексы, имеющие тенденцию к азимутальному размытию. Рефлексы с азимутальным размытием отсутствуют на электронограммах, полученных с участков, принадлежащих только мартенситным пластинам (рис. 7). Сдавливание остаточной аустенитной фазы со стороны мартенсита приводит к напряжениям и разориентации, изначально когерентных матрице областей, что, в свою очередь, отражается в азимутальном размытии рефлексов.

Наблюдаемые в настоящей работе особенности тонкой структуры клинообразной фольги сплава $\mathrm{Ni}_{46} \mathrm{Mn}_{41} \mathrm{In}_{13}$ коррелируют с результатами работы [19], в которой сделан анализ имеющихся в литературе данных о влиянии размера нанокристаллов сплавов $\mathrm{NiFeGa}$ и TiNi на параметры кривых их псевдоупругой и термоупругой деформации. Этот анализ предполагает существование критического размера нанокристалла $D_{k}$, меньше которого мартенситное превращение в кристалле отсутствует. Кроме того, работе [19] сформулированы кинетические нелинейные уравнения для объемных долей мартенсита и аустенита, решение которых показывает, что они описывают процесс самоорганизации дислокаций превращения, в результате чего в кристалле формируется доменная структура с межфазными границами. 


\section{4. Заключение}

Полученные результаты демонстрируют, что фазовое превращение в сплаве $\mathrm{Ni}_{46} \mathrm{Mn}_{41} \mathrm{In}_{13}$ происходит неравномерно по всему образцу, о чем свидетельствует разнообразие наблюдаемых структур (черно-белый контраст, твид, ламельная структура). Ниже $M_{s}$ кубическая L2 1 фаза превращается в модулированные мартенситные варианты с остаточным аустенитом. Дальнейшее снижение температуры приводит к увеличению доли мартенситной фазы, однако обнаружено, что мартенситное превращение полностью подавляется при толщине пластины менее $50 \mathrm{~nm}$.

Температуры прямого и обратного мартенситного превращения зависят не только от величины магнитного поля, но и от размеров и конфигурации образца. Уменьшение толщины пластины и магнитные поля приводят к снижению температуры прямого мартенситного превращения, расширяя область существования ферромагнитного аустенита.

\section{Финансирование работы}

Исследование выполнено за счет гранта Российского научного фонда (проект № 20-79-10197).

\section{Конфликт интересов}

Авторы заявляют, что у них нет конфликта интересов.

\section{Список литературы}

[1] S.B. Madiligama, P. Ari-Gur, V.G. Shavrov, V.V. Koledov, S. Calder, A.V. Mashirov, A.P. Kamantsev, E.T. Dilmieva, L. Gonzalez-Legarreta, B.H. Grande, V.V. Vega, A. Kayani. Smart Mater. Structures 8, 085013 (2016).

[2] Yu.S. Koshkid'ko, E.T. Dilmieva, J. Cwik, K. Rogacki, D. Kowalska, A.P. Kamantsev, V.V. Koledov, A.V. Mashirov, V.G. Shavrov, V.I. Valkov, A.V. Golovchan, A.P. Sivachenko, S.N. Shevyrtalov, V.V. Rodionova, I.V. Shchetinin, V. Sampath. J. Alloys Comp. 798, 810 (2019).

[3] А.П. Каманцев, В.В. Коледов, А.В. Маширов, Э.Т. Дильмиева, В.Г. Шавров, Я. Цвик, И.С. Терешина, М.В. Лянге, В.В. Ховайло, Дж. Поркари, М. Топич. Изв. РАН. Сер. физ. 79, 9, 1230 (2015).

[4] Н.И. Коуров, А.В. Королев, В.Г. Пушин, В.В. Коледов, В.Г. Шавров, В.В. Ховайло. Физика металлов и металловедение 99, 4, 38 (2005).

[5] В.Г. Пушин, Н.И. Коуров, А.В. Королев, ВА. Казанцев, Л.И. Юрченко, В.В. Коледов, В.Г. Шавров, В.В. Ховайло. Физика металлов и металловедение 99, 4, 64 (2005).

[6] E. Kalimullina, A. Kamantsev, V. Koledov, V. Shavrov, V. Nizhankovskii, A. Irzhak, F. Albertini, S. Fabbrici, P. Ranzieri, P. Ari-Gur. Physica Status Solidi C 11, 5-6, 1023 (2014).

[7] A.P. Kamantsev, V.V. Koledov, A.V. Mashirov, E.T. Dilmieva, V.G. Shavrov, J. Cwik, A.S. Los, V.I. Nizhankovskii, K. Rogacki, I.S. Tereshina, Y.S. Koshkid'ko, M.V. Lyange, V.V. Khovaylo, P. Ari-Gur. J. Appl. Phys. 117, 16, 163903 (2015).

[8] J. Liu, Z. Liu, X. Jin. Phil. Mag. 94, 1, 56 (2014).
[9] В.Г. Пушин, Е.Б. Марченкова, А.В. Королев, Н.И. Коуров, Е.С. Белослудцева, А.В. Пушин, А.Н. Уксусников. ФТТ 59, 7, 1297 (2017).

[10] С.В. Сударева, Е.И. Кузнецова, Т.П. Криницина, И.Б. Бобылев, В.Н. Морычева, Л.В Жердева, Е.П. Романов. Физика металлов и металловедение 75, 2, 125 (1993).

[11] H. Nath, G. Phanikumar. Mater. Characterization 102, 24 (2015).

[12] Y. Ni, Y. M. Jin, A.G. Khachaturyan. Acta Mater. 55, 4903 (2007).

[13] Y. Ni, A.G. Khachaturyan. Nature Mater. 8, 410 (2009).

[14] Y.M. Jin, Y.U. Wang, Y. Ren. npj Comput. Mater. 1, 15002 (2015).

[15] P. Lega, A. Kartsev, I. Nedospasov, S. Lv, X. Lv, N. Tabachkova, V. Koledov. Phys.Rev. B 101, 21, 214111 (2020).

[16] T. Waitz, T. Antretter, F.D. Fischer, N.K. Simha. J. Mech. Phys. Solids 55, 419 (2007).

[17] Y.Q. Fu, S. Zhang, M.J. Wu, W.M. Huang, H.J. Du, J.K. Luo, A.J. Flewitt, W.I. Milne. Thin Solid Films 515, 80 (2006).

[18] С.В. Сударева, Е.П. Романов, Т.П. Криницина, Ю.В. Блинова, Е.И. Кузнецова. Физика металлов и металловедение 102, 221 (2006).

[19] Г.А. Малыгин. ФТТ 61, 2, 288 (2019).

Редактор Т.Н. Василевская 